\title{
CONTRIBUTION OF IVAN GAMS TO THE DEVELOPMENT OF SLOVENE KARST TERMINOLOGY
}

\author{
PRISPEVEK IVANA GAMSA K RAZVOJU SLOVENSKE \\ KRAŠKE TERMINOLOGIJE
}

JURIJ KUNAVER ${ }^{1}$

${ }^{1}$ Jurij Kunaver, Ph. D., Full Prof., Hubadova 16, 1113 Ljubljana, Slovenija

Prejeto / received: 4. 9. 2003 


\section{Jurij Kunaver: Contribution of Ivan Gams to the development of slovene karst terminology}

The stage of the scientific terminology is by all means one of the indicators of the development of the scientific branch, to which it belongs. Therefore the publishing of the Slovene karst terminology in 1973 was an important event for further development of Slovene karstology. Still more, the efforts for a comparative national karst terminologies of former common state Yugoslavia were successfully achieved in publishing the Serbian and Croatian karst terminology also, a year later. In fact, the former Association of the geographical societies of Yugoslavia decided to give full support to its subcommission in preparing the project Karst terminology of the Yugoslave nations and to a joint Yugoslave symposium on Karst terminology, held in Ljubljana from 22-23th October 1971, both guided and organised by prof. Ivan Gams, who was also the original initiator of this idea. All this efforts were newertheless combined and connected with the international work of that time to find most appropriate terms and definitions for the karst phenomena and to make them comparable in terms of national terminologies. Ivan Gams was therefore not only a most important promoter of the Slovene karst terminology and one of the leading persons of the scientific karstology in the time concerned but was due to his global ideas also one of the central persons in the international karstology.

Key words: Ivan Gams, karstology, terminology, Slovenia.

Izvleček

UDK: 551.44:929 Gams. I.

\section{Jurij Kunaver: Prispevek Ivana Gamsa k razvoju slovenske kraške terminologije}

Razvitost znanstvene terminologije je eden od pomembnih kazalcev stanja v posamezni znanstveni veji. Zato je pomenila izdaja Slovenske kraške terminologije leta 1973 pomembno dejanje in prelomnico v slovenskem krasoslovju. Leto pozneje sta izšli tudi podobni terminologiji v srbskem in hrvaškem jeziku, vse to pa je bila posledica odločitve takratne Zveze geografskih organizacij Jugoslavije o jugoslovanskem znanstvenem simpoziju o kraški terminologiji, ki je bil v Ljubljani od 22.-23. oktobra 1971. Za vsem tem je stal prof. Ivan Gams, ki je bil ne samo pobudnik ampak tudi izvajalec te akcije. A tudi po njegovi pobudi so se slovenski krasoslovci v tem pogledu prebudili že deset let prej, leta 1962, ko je bil v okviru Geografskega društva Slovenije prvi posvet na to temo. Začetki samostojne slovenske krasoslovne terminologije segajo celo v drugo polovico 19. stoletja, ko so bili s prvim vodnikom o Postojnski jami avtorja Coste (1863), pisanim v slovenščini, postavljeni njeni prvi znanstveni temelji. Ivan Gams pa je skupaj s sodelavci pred tridesetimi leti z izdajo sodobno zasnovane Slovenske kraške terminologije, opremljene s tujejezičnimi sopomenkami, omogočil njen enakopraven mednarodni položaj ob boku drugih terminologij, s tem pa prispeval tudi $\mathrm{k}$ narodni in znanstveni samozavesti.

Ključne besede: Ivan Gams, krasoslovje, terminologija, Slovenija. 
Terminology is the key tool of every branch of science, its indispensable and essential companion and therefore the basis of the scientific language and understanding. It is the common denominator, accepted by scientists, although with compromises, and at the same time it can be the subject of animated discussions. Terminology is the touchstone of scientific power and intellectual innovativeness of individuals and the whole branch of science. In the proceedings on "the science of terminology" (Pedagogical Institute of the University of Ljubljana, 1984) one can read: "Every field of science has to determine the subject it treats and discusses, the methodologies it uses, as well as the symbolically, semantically and informationally pure terminology. Terminology is therefore an indicator of development, structure, integrational and communicational skills of the branch of science, as well as of the economical and social development and progress. Terminology thus reflects the subjects, the problems, the evolution and the values of a certain branch of science" (Pediček, 1984, 5-6, 13). In the proceedings, the physicist Strnad explains his notion of terminology with the two ways to terminology: "The first way is the natural way to terminology in school through textbooks, the other one leads through dictionaries and glossaries. Short and independent explanations are typical of the latter, although they might not always be professionally irreproachable. In this case compromises are inevitable. The experts of the branch should have the final say, however, they sometimes lack the feeling for the needs of glossaries or dictionaries. When so, the linguists are required" (Strnad, 1984, 144). From our own experience we could add the third possible way, the scientific way, which tests the existing terms and suggests new ones.

This could be a short summary of the essence, importance and problems of every scientific terminology. In my paper I would like to explain the circumstances of making the Slovene karst terminology, as I participated in this process, which I find a significant phase in the Slovene karstology. This was the time when not only Slovenian and former Yugoslavian, but also experts from other countries realized they needed more accurate and thorough terms and definitions in their field of explorations. In our country, as well as in other European countries, some basic explorations of particular types and areas of the Karst region were made at that time, and along with discovering new characteristics of the Karst, new terms and definitions were introduced. I went through this myself while introducing terminology for mountain karst phenomena, for instance tiny corrosional shapes, and I always used to come across the rest of the karst terminology. Without hesitating we can make a reconstruction of some past facts and events, and illuminate the role of Prof. Ivan Gams, the most active and deserving person for our own terminology for karstology. This terminology has put us alongside bigger and more developed nations. Although the Slovene karst terminology had a national character, it already included elements of the former mentioned skills of communication and comparison, partly because of the very extensive project (according to the number of participating individuals and organizations), as well as because of the previously collected equivalent terms in English, French, Croatian, Serbian and Macedonian. 


\section{THE SITUATION BEFORE THE APPEARANCE OF THE SLOVENE KARST TERMINOLOGY}

The efforts to create a thorough karst terminology are presented mostly in Slovene, Croatian and Serbian terminologies, published one after another in early seventies as a result of a wellorganized joint activity, initiated and led by Ivan Gams. The first efforts, however, started a decade earlier, in 1962, when The Geographical and Geological Society of Slovenia organized a conference on these themes (published in Geografski vestnik, 1962, 115-137). Ivan Gams was one of the initiators again, and he gathered even more experts than a decade later. We could say that the first systematic and quite thorough collection of Slovene karst terms, the basis for further scientific work, was established then, and later it was only completed and re-formed. Gams stated that the Slovene karst terminology, too, was a result of "the historical development of the branch" and that the Slovenes started creating it relatively late. It was characteristic of those days, that we were trying to introduce the term »vrtača«, instead of »kraška dolina«, which was mostly used before. We began to distinguish more precisely the terms like »ponor«, "ponikva« and "požiralnik « (Gams, 1962, 115). A more detailed survey on the Alpine karst forms and terms for them was introduced (Kunaver, 1963, 123-129). Two years later the committee for terminology at the Society of Cave Explorations of Slovenia discussed the problems of the karst terminology, and a year later the Speleological section of PD Železničar followed them (Novak, 1974, 147).

If we want this review to be complete, we must not forget to mention the very beginning of gathering the Slovene karst terms in the second half of 19th century, when terms like »siga« for sinter (Cigale, 1860, taken from Croatian) and »kapnik" for a dripstone appeared in the first Slovene guidebook about the Postojna Cave (Costa, 1863). This guidebook introduced some new terms and can be considered the very first Slovene written terminology about the Karst explorations, and its author Costa "the founder of the Slovene speleological terminology" (Habe, 1974, 111; Kranjc, 1980, 85-87). The term "kapnik" was accepted sooner than "siga", due to the influence of German authors (Hohenwart, Schmidl, Zippe), hence the more frequent use of the "kapniške tvorbe" compared to the "sigove tvorbe", as stated by I. Gams (1980, 89-90). According to Habe, along with the Slovene guidebooks about the Postojna caves from $19^{\text {th }}$ century the biggest contribution to introducing Slovene terms in the field of physical geography and karstology was given by Janez Jesenko from Trieste, with his textbooks Obči zemljepis (General Geography) (1873) and Prirodoznanski zemljepis (Physical Geography) (1874), a fact that is not widely known.

In October 1969 the committee for scientific researches at the Association of Geographical Institutions of Yugoslavia decided to include a Yugoslav symposium on the karst terminology and typology of the Karst region in their long-term interests. In spring 1970 the committee entrusted the organization of the symposium to the Department of Physical Geography at the Department of Geography at the Faculty of Arts in Ljubljana, where the idea for it first came from. The symposium took place the next autumn, 21-22 ${ }^{\text {nd }}$ October 1971. There were four main papers delivered at the symposium on karst terminologies in the former Yugoslav republics, followed by four co-reports, which came from Slovenia. That proves that most aspirations for the karst terminology in this part of Europe have come from Slovenia. One of the reasons was the organization of $4^{\text {th }}$ International Speleological Congress, which brought valuable international connections and initiatives; the other reason was probably the fact that many individual experts had done explorations of separate types 
of the Karst before, like the Alpine karst, the karst of depressions or »koliševke«, karst valleys, big cave systems in Notranjska region, waters of the Slovene karst and many others. Scientific explorations of the Slovene karst and terminology went in three ways: within the Dept. of Physical Geography at the Department of Geography at the Faculty of Arts in Ljubljana, at the Karst Research Institute at the Slovene Academy of Sciences and Arts in Postojna, and within the Geological Institute of Slovenia. Beside these there were unprofessional institutions for cave explorations of that time, like the Chair of Quaternary Research, the Slovene Caving Society and the Society of Cave Exploration in Ljubljana, mentioned in Terminology. Professional contacts among those institutions were not very intense in the sense of joint projects or other scientific work; therefore one could feel some rivalry, competition and distrust among them. Creating terminology of a branch has always been a prestige task. The leader of the action, however, realized how important it was to join all the eminent experts of the branch. The complete action, which started in 1970 at the Chair of Physical Geography by making a list of terms and dividing it among different institutions, was meant as a collective work. However, the organizers were not very successful in this, as some institutions had conflicting interests, refusing to be second fiddle. In the final phase of preparing the terminology the group had only three members, although there are five other names on the cover of the publication, representatives of the then institutions of the karst explorations. Nevertheless Terminology got a national character and importance and it reflected the position of karstology in our country.

\section{HOW WE WORKED}

I would like to say some words about how we worked. The most effective method, besides collecting written and oral comments, led by Prof. Gams, was team or collective creating of definitions and checking their adequateness. Ivan Gams, Darko Radinja and myself were members of the editorial board, which had to decide upon the final definition. We simply wrote the definition on the blackboard and kept improving it until we were all satisfied or ready to accept a compromise. Most of those who participated in the process were content with this kind of work, except for those who could not or did not want to cooperate. Despite of some differences in our opinions we managed to earn mutual confidence and respect. Today I would recommend such kind of teamwork to anyone who wants to start a project like this, supported by computers, of course.

\section{RESPONSES TO THE PUBLISHING OF TERMINOLOGY}

As Gams wrote in The Short History .... the symposium initiated "the more active work in forming karst terminology also with other Yugoslav nations and defined the guidelines of their work" (Gams, 1973c, 34). Most of the critics of the Terminology realized that "what was done then, was not the final version, yet it helped and supported the scientific reference books" (Novak, 197, 147), according to Šušteršič it was "an indicator or expositor of the situation at that moment". He was very critical about the Terminology, saying that "Terminology does not consider the local folk's terminology enough" (he cites Badjura), and beside this "some terms are a direct translation of German terms". Šušteršič thought that the authors did not follow "the tradition of Slovene speleology enough ... and thus impoverished the language" (Šušteršič, 1974, 148). Perhaps the 
critic overlooked another purpose of Terminology, namely, that it was not only meant for Slovene, but also for foreign readers. Therefore considering folk terminology would not make sense and is not so much used in other fields. Unfortunately Badjura did not provide proper terms for tiny corrosional forms. In the editorial to Gavrilović's Serbian Karst Terminology we can read that "looking for new terms among folk expressions might be disputable, because they usually name only the basic or biggest relief forms" (Gavrilović, 1974, 15).

If we want to find out how the Slovene karst terminology has changed, as F. Šušteršič predicted, and point out the open questions, we can state the following. According to Šušteršič (oral communication) the discrepancy between certain terms and the genesis of the phenomenon which it represents, has become bigger. After him too many terms rely on their genesis, as it can change after some time. Therefore the correctness of such terms is disputable. He mentions an example of "udornice", which are proved to be of a different origin than understood from the term. Šušteršič still prefers the term "dolina" to "vrtača".

One can conclude that creating appropriate terminology for a wide range of users is a very demanding task, never absolutely finished and never satisfactory for everyone. Often it is about different expert opinions and starting points, different understanding of the same thing, which is absolutely legitimate and normal. But sometimes it is also about different attraction to the same words and their meanings, as well as about a subjective attitude towards their authors. A typical example is the term "vrtača", the majority agreed upon, but some experts still argue about it. I believe it is better to finish terminology as quickly as possible, and not to wait for too long, regardless of possible inexactness. This was also Prof. Gams's main principle, which I still find correct. Each terminology, based on expert opinions and suggestions, reflects its time and offers a starting point for the future, exposed to critics, of course. If the critics have cogent arguments, the term can be changed, otherwise better not, irrespective of its original meaning. Some branches prefer to use borrowed expressions and replacing them with new ones can cause serious inconveniences. We do not argue for the intangibility of terminology, but for its practical value. Irrespective of how thorough a collection of non-published terms can be, it does not have any practical value.

\section{EFFORTS FOR KARST TERMINOLOGIES OUTSIDE SLOVENIA}

I am going to mention only some terminologies, published after World War II. We have to bear in mind that every textbook represents a collection of karstology terms, thus terminologies were of greater importance at the times, when there were few textbooks available. The Russian terminology is one of the latest terminologies, published in 1991, including more than 2500 terms. Tendencies to collect as many terms as possible and offer them to the experts to use and complete them began first after World War II. Among others there was a well known report by G. Chabot (1956), Rapport sur le vocabulaire karstique, Report of the Commission on Karst Phenomena, IGU, Rio de Janeiro, followed by Vergleichendes Vokabulär für den Formenschatz des Karstes, prepared by Herbert Lehmann, for the collection Geographisches Taschenbuch in 1958/59. The next terminology was Speläologisches Fachwörterbuch, edited by Hubert Trimmel, published in 1965, also as a publication of $3^{\text {rd }}$ International Speleological Congress (1961, Vienna, Obertraun, Salzburg), which consisted of 750 terms. The International Committee for Karst Terminology 
was most active at the time of Slovene biggest endeavours in this field. In autumn 1971 a conference was organized in Obertraun in Salzkammergut, led by Max Fink. The result of the conference was among others the unpublished report Multilingual glossary of karst and speleological terminology (Fink 1973), ISU, Subcommission on Karst terminology. The conference was of great importance for us, young researchers in that time, because we were able to present the Slovene point of view and experiences in creating proper terminology, we got acquainted with renowned scientists, and were able to do some fieldwork and learn about Alpine karst phenomena. It became clear to us that bigger nations and languages have no absolute priorities or privilege over smaller nations in suggesting scientific terms, so every nation has the same possibilities to contribute to the science.

We should also mention the efforts to put the terms "kotlič" and "konta" into the international terminology, in which we at least partly succeeded (Kunaver, 1973, 68). The term "kotlič" is mentioned in works of M. M. Sweeting, D. Ford, in the Anglo-American reference books, in Panoš Karstological and Speleological Terminology (2001, over 1850 terms) and elsewhere; "konta", however, can be found in the Russian terminology. It is to be regretted that the Slovene karstology, except for caving, deals much more with the Dinaric than Alpine karst. There are fewer scientific explorations and therefore less support for the Alpine karst, also in introducing Slovene terms of this area abroad. During the process of creating the terminology it was sometimes very difficult to achieve equal evaluation of certain Alpine or microkarst terms, and therefore many terms were not put in the terminology, because of some "subjective criteria, which still deny the existence of certain phenomena ... e.g. microcorrosional ...in the Slovene karst terminology", and they are still waiting to be accepted (Kunaver, 1973, 69). Nevertheless, these terms finally found their place in the Slovene karst terminology, not on the list of terms, however, but in a separate paper, later used as groundwork for further discussions and debates. We must not forget to mention here the founders of small corrosional and Alpine karst phenomena system, especially O. Lehmann, F. Bauer, K. Haserodt and A. Bögli. We would not like this part of Slovene karst terminology to stand aside and depend on very few interested individuals. In spite of many international connections it has been left behind, partly while explorers of the Alpine karst have been more interested in the karst underground phenomena in the last few decades than in its surface.

Most work on the internationally applicable terminology of the Alpine karst was done by Alfred Bögli, among others with his short paper Die wichtigsten Karrenformen der Kalkalpen, published in 1978 in Ljubljana. He compared most suitable terms in German, English and French, but he did not or could not consider Slovene terms (Bögli, 1978, 14-49).

The list of successes, at least indirectly influenced by Ivan Gams, his vision and his organizational skills, includes also the Serbian and Croatian terminologies. They were both published a year later than the Slovene one. In 1974 Dušan Gavrilović edited the Serbian version, which contained about 400 terms; the Croatian, however, included 551 terms and was edited by Josip Roglić. In our report on the Serbian terminology in 1974 we mentioned that it contained fewer terms, but the explanations were richer than in the Slovene terminology (515 terms). Roglić's terminology had even more extensive explanations (Kunaver, 1974, 152-153).

Let me summarize some statements of both editors, which have influenced the further development of karstology and its terminology in certain environments, or are still in use today. Gavrilović found that the development of karstology in Serbia stagnated after Cvijić. He cited J. Cvijić: "It has not been done enough about general geographical terminology and especially about karstology terminology, furthermore, some authors have given certain terms completely opposite 
meanings." This was said to be true at the time of publishing their terminology (Gavrilović, 1974, 13). Gavrilović argues about the origin of the terms "polje", "vrtača", "estavela", "bogaz", about some hydrological terms, the use of the general name "kras", "karst" or "krš", about "siga" and other old and new karst terms. He also mentions inaccurate definitions of some terms of local importance ("muzga", "čebelj”, "zvekara", "bezdan”, etc.), which do not correspond to scientific terminology, although used in textbooks. Gavrilović pointed out the need for more explicit and precise scientific and public critics in this field (Gavrilović, 1974, 15-16).

From Roglić's report one can understand that there are still many little known folk expressions and names in Croatia, which could be of greater use in scientific work. The karstology terminology reflects the fact, that national heritage was not yet investigated thoroughly in that time. Roglic found the terms too dependent on translations from foreign languages, especially from German. He was obviously not satisfied with the Croatian version of karst terminology, so he tried to stimulate further scientific work. He pointed out the inaccurate genetic terms, while their background might be too hypothetical (Roglić, 1974, 3-4).

\section{CONCLUSION}

The development of sciences with a history and tradition of many centuries seems to be obvious. However, for a small nation, which fought for its national, cultural and political independence and recognition for many centuries, aspirations for its own science went together with many strains and struggles, optimism and belief in its own creativity. All the efforts to get national terminologies, in our case of the karst, in a way represent the invincible wish for life, success and equal cooperation with other nations. We could say that we were often helped by the nature of our country, especially the karst, which contributed a lot to our national and scientific awareness, with the help of the Slovene karst terminology by Ivan Gams, too. The story does not end here. We hope it will be continued in further chapters, as predicted by the new generations of researchers. They, and perhaps we, too, might find the existent terminological frames too tight soon. This is called evolution, and this is how it should be.

\section{REFERENCES:}

Bögli, A. 1978: Die wichtigsten Karrenformen der Kalkalpen. Karst processes and relevant landforms. International Speleological Union, Commission on Karst denudation. Department of Geography, Philosophical Faculty, University of Ljubljana. Ljubljana, 141-149.

Chabot, G., 1956: Rapport sur le vocabulaire karstique. Report of the Commission on Karst Phenomena, IGU, Rio de Janeiro.

Fink, M. H., 1973: Multilingual glossary of karst and speleological terminology. ISU, Subcommission on Karstterminology. Project.

Gams, I, 1962 a: Kraška terminologija. Uvodna pojasnila. Geografski vestnik, 34, 1962, 115-116.

Gams, I, 1962 b: Terminologija večjih kraških oblik. Geografski vestnik, 34, 1962, Ljubljana, 116-122.

Gams, I. \& J., Kunaver \& D., Radinja, 1973 a: Slovenska kraška terminologija. Katedra za fizično geografijo oddelka za geografijo FF, Univerza v Ljubljani, Ljubljana, 76 p.

Gams, I. , 1973 b: Načela, po katerih je sestavljena ta terminologija. Slovenska kraška terminologija. 
Katedra za fizično geografijo oddelka za geografijo FF, Univerza v Ljubljani, Ljubljana, 3233.

Gams, I. , 1973 c: Kratek historiat nastanka te terminologije. Slovenska kraška terminologija. Katedra za fizično geografijo oddelka za geografijo FF, Univerza v Ljubljani, Ljubljana, 34-35.

Gams, I. , 1973 d: Razvoj slovenskih besed kras in dolina v mednarodna termina do konca 19. stoletja. Slovenska kraška terminologija. Katedra za fizično geografijo oddelka za geografijo FF, Univerza v Ljubljani, Ljubljana, 39-54.

Gams, I. , 1973 e: Terminologija tipov kraških polj . Slovenska kraška terminologija. Katedra za fizično geografijo oddelka za geografijo FF, Univerza v Ljubljani, Ljubljana, 55-67.

Gams, I., 1980: Sigove tvorbe-kapniki-Kras-kras. Prispevka k slovenskemu kraškemu imenoslovju. GV 52, 1980, Ljubljana, 89-92.

Gavrilović, D., 1974: Srpska kraška terminologija. Kraška terminologija jugoslovenskih naroda, knjiga II. Savez geografskih institucija Jugoslavije, Beograd, 73 p.

Habe, F., 1972: Mednarodna delovna konferenca za kraško terminologijo, 12.-17. Sept. 1971, Obertraun, Avstrija. Naše jame 13 (1971), Ljubljana, 130-131.

Habe, F., 1974: Nekaj o začetkih slovenskega speleološkega izrazoslovja. Naše jame 15 (1973), Ljubljana, 111-115.

Jenko, F., 1962: Kraško izrazoslovje v hidrologiji in hidrotehniki. Geografski vestnik, 34, 1962, Ljubljana, 132-133.

Kranjc, A., 1980: Siga. Prispevek k slovenskemu kraškemu imenoslovju. GV 52, 1980, Ljubljana, 85-88.

Kunaver, J., 1962: Terminologija visokogorskih kraških oblik. Geografski vestnik, 34, 1962, Ljubljana, 123-129.

Kunaver, J., 1973: O razvoju slovenske terminologija za mikroreliefne kraške oblike (nekaj misli in predlogov ob primeru visokogorskega krasa). V: Gams, I., J., Kunaver, D., Radinja, 1973. Slovenska kraška terminologija. Katedra za fizično geografijo oddelka za geografijo FF, Univerza v Ljubljani, Ljubljana, 68-76.

Kunaver, J., 1974: Gavrilović Dušan, Srpska kraška terminologija. Geografski vestnik, 46, 1974, Ljubljana, 152-153.

Novak, D., 1962: Kraške oblike z vodno funkcijo. Geografski vestnik, 34, 1962, Ljubljana, 129130.

Novak, D., 1974: Slovenska kraška terminologija. Geografski vestnik, 46, 1974, Ljubljana, 147.

Panoš, V., 2001: Karsologická a speleologická terminologie. Výkladový slovník s ekvivalenty ve slovenštině a jednacích jazycích mezinárodní speleologické unie (UNESCO) (angličtina, francouzština, italština, němčina, ruština, španělština). Knižne centrum, Žilina, 352 p.

Pediček, F., 1984 a: Predgovor. Terminologija v znanosti. Prispevki k teoriji. Zbornik. Pedagoški inštitut pri univerzi Edvarda Kardelja v Ljubljani, Ljubljana, 5-7.

Pediček, F., 1984 b: Uvod v vprašanje. Terminologija v znanosti. Prispevki k teoriji. Zbornik. Pedagoški inštitut pri univerzi Edvarda Kardelja v Ljubljani, Ljubljana, 13-15.

Roglić, J. \& V. Birga, 1974: Prilog hrvatskoj krškoj terminologiji. Krš Jugoslavije, 9/1, Zagreb, $72 \mathrm{p}$.

Savnik, R., 1962: Poimenovanje kraških jam. Geografski vestnik, 34, 1962, Ljubljana, 133-135.

Strnad, J., 1984: O fizikalni terminologiji. Terminologija v znanosti. Prispevki k teoriji. Zbornik. Pedagoški inštitut pri univerzi Edvarda Kardelja v Ljubljani, Ljubljana, 143-145. 
Šušteršič, F., 1974: Slovenska kraška terminologija. Geografski vestnik, 46, 1974, Ljubljana 148150.

Timofeev, D.,A.\& V. N. Dubljanskij, T., Z., Kiknadze, 1991: Terminologija karsta. Materiali po geomorfologičeskoj terminologiji. Nauka, Moskva, $260 \mathrm{p}$.

Trimmel, H., 1965: Spelälogisches Fachwörterbuch (Fachwörterbuch des Karst- und Höhlenkunde). In Verbindung mit einer Arbeitsgemeinchaft des Landesvereines fur Höhlenkunde in Wien und Niederösterreich. Herausgegeben vom Landesvereines fur Höhlenkunde in Wien und Niederösterreich, Wien, $109 \mathrm{p}$. 